[Competency Approach in Modern Education: World Experience and Ukrainian Perspectives: Library of Educational Policy]. Kyiv: "K.I.S.”, 112 p. [in Ukrainian].

8. Pometun, O.I. (2005). Formuvannia hromadianskoi kompetentnosti: pohliad $z$ pozytsii suchasnoi pedahohichnoi nauky [The formation of civic competence: a view from the standpoint of modern pedagogical science]. The herald of School Exchange Programs, no. 23, pp. 18-20. [in Ukrainian].
9. Telychko, N.V. (2014). Profesiina kompetentnist yak bazova osnova pedahohichnoi maisternosti vchytelia pochatkovykh klasiv [Professional competence as a base of pedagogical mastery of teachers of elementary school]. The scientific herald of the National University of Bioresources and Nature Management of Ukraine. Series: Pedagogy, Psychology, Philosophy. Vol. 199(1), pp. 376-383. Available at: http://nbuv.gov.ua/UJRN/ nvnau_ped_2014_199(1)_61. [in Ukrainian].

Стаття надійшла до редакції 01.02.2018

УДК 784.4(477.83 - 25) “18 - 19”

Андрій Ковбасюк, кандидат мистеитвознавства, доцент кафедри музикознавства та хорового мистецтва факультету культури і мистеитв Львівського національного університету імені Івана Франка

\title{
СПАДКОСМНІСТЬ ПІСЕННО-ФОЛЬКЛОРНОЇ ТРАДИЦІЇ В МУЗИЧНОМУ ЖИТТІ ЛЬВОВА КІНЦЯ ХІХ - ХХ СТОЛІТЬ
}

Розкрито пісенно-фольклорну складову львівської музичної культури кіния ХІХ - ХХ століть. Виокремлено осередки популяризаиї̈ народної пісні у Львові. Висвітлено український пісенний фольклор як засіб наиіонально-суспільного самовираження. Зроблено історичний аналіз розвитку музичного життя Львова кінці XIX-XX століть в контексті української пісенно-фольклорної традиції. Визначено, щэо рівень пісенної культури народу Галичини є яскравим показником його загального духовного розвитку.

Ключові слова: украӥнська народна пісня, пісенно-фольклорна традиція, музична культура, музичне життя Львова.

תim. 5.

Andriy Kovbasyuk, Ph.D.(Art Studies), Associate Professor of the Musicology and Choral Art Department Faculty of Culture and Arts Lviv Ivan Franko National University

\section{SUCCESSION OF THE MUSIC AND FOLK TRADITIONS OF LVIV MUSICAL LIFE LATE XIX - XX CENTURY}

The song and folklore component of the Lviv musical culture at the end of the 19th and 20th centuries is revealed. The song and folklore component of the musical life of Lviv at the end of the 19th and 20th centuries was presented in many directions, namely: in artistic and stage activities, performing interpretations, composer stylistics and in the musical and educational sphere. The Ukrainian song folklore as a means of national-social expression is highlighted. The self-awareness of the Ukrainian nation for centuries has been exerted in the musical arts (most in the song's creation) as a form of the national and social expression. Thanks to this fact, Ukrainians managed to survive as a nation and not to lose their culture. Ukrainian singing was also used as a form that provided the ample opportunity for the realization of the educational aspirations of the Galician intelligentsia. A historical analysis of the development of musical life of Lviv at the end of the 19th and 20th centuries in the context of the Ukrainian song and folklore tradition was made. It is determined that the level of song culture of the people of Galicia is a vivid indicator of its general spiritual development. Lviv.

Keywords: Ukrainian national song, the music and folk traditions, the music culture, the music life of

П остановка проблеми. Народну культуру та мистецтво українців слушно вважають одними 3 найбагатших надбань культурної спадщини $\epsilon$ вропейських націй. Відомо, що українська культура володіє розкішною пісенною спадщиною, яка породжена фольклорною традицією та опосередкована через творчість великої кількості мистців. Саме 3 цієї причини вивчення впливу народної пісні на формування регіональної музичної культури має важливе значення і є актуальним об'єктом наукових розвідок.

Попри всі відмінності в мистецькому розвитку різних регіонів України, друга половина XIX століття всюди позначена опануванням i переосмисленням “інтонаційних кодів" української народної пісні упрофесійній музичній культурі. Відбувається процес формування глибоко народного й реалістичного мистецтва. 
Великий інтерес у зв'язку з цим викликала народна пісня. Фольклористи, композитори, виконавці беруть активну участь у збиранні народної пісні, іiі художній обробці, виявленні іï специфічних особливостей.

Аналіз останніх досліджень та публікацій. Висвітленню мистецтвознавчого аспекту розвитку музичної культури в Галичині присвячені роботи численних музикознавців та літературознавців-фольклористів (М. Загайкевич, Л. Кияновська, С. Павлишин, Г. Нудьга та ін.). Особливу увагу в наукових працях приділено вивченню тих процесів, які виокремлюють характерні риси становлення національних форм культури у Західній Україні, зокрема Галичини, як центру, що сфокусовано їх узагальнює (Н. Кобрин, Н. Костюк, Л. Кияновська, Н. Майчик, М. Черепанин та ін.).

Метою статті $\epsilon$ спроба зробити історичний аналіз розвитку музичного життя Львова кінці XIX - XX століть в контексті української пісеннофольклорної традиції.

Виклад основного матеріалу. Для західноукраїнського мистецтва кінець ХІХ - ХХ ст. культурного життя характеризується передусім постійною орієнтацією на фольклор, на те, що для української культури вельми важливим $є$ пісня, епос, обряд. Саме пісенність - не як конкретний жанр, а як узагальнена естетична категорія, з їі стійкими метафорами, символами, персонажами і сюжетними поворотами міцно увійшла як елемент художнього мислення в професійне українське мистецтво. Українська пісенність використовувалася також як форма, що надавала широкі можливості для реалізації просвітницьких прагнень галицької інтелігенції.

Музично-суспільний рух концентрувався у хорах і музичних гуртках при різних товариствах та успеціальних музичних установах. У 1838 році було засновано одну з найвідоміших музичних організацій Львова - Галицьке Музичне Товариство (ГМТ). 3 утворенням цього Товариства розпочався новий період у розвитку професійного мистецтва Галичини. Від цього часу розпочинається славна історія професійних музичних закладів у Львові.

Залежно від походження, місця і функцій у суспільстві, естетичного рівня, виокремлено: церковні хори, що формували пласт масової музики; хори й оркестри при товариствах певного фахового чи соціального складу (найвідоміші академічний хор “Бандурист”, хори та оркестри ремісничого товариства “Зоря”, оркестр товариства “Основа”); хор“Просвіта", “Муза”); музичні гуртки товариств (“Січ”, “Сокіл”,
“Пласт”); спеціальні музичні організації (хорове товариство “Боян”, що мало у Галичині орієнтовно 25 філій.

Діяльність “Боянів” переважно грунтувалася на пропаганді народних пісень й досягнень української професійної музики, попри те, що у їхньому репертуарі були й твори світової музичної спадщини.

I саме хорові товариства переважали у музичному житті Львова та й усієї Галичини, бо за їхнім типом організації наприкінці XIX початку XX століть виникатимуть численні дочірні товариства в різних містах Галичини (яскравий приклад - виникнення розгалуженої мережі “Боянів"). Отже, їхнє значення для розвитку української музичної культури важко переоцінити $[3,76]$.

Метою культурно-мистецьких товариств було залучення широких верств населення до музичної й пісенної культури; підтримка художньо обдарованої молоді; пропагування національного мистецтва й культурних цінностей у найвіддаленіших куточках західноукраїнських земель; розширення мережі культурно-мистецьких освітніх установ; координування їхньої діяльності.

Давні традиції має музично-театральна культура Львова. Українська народна музика була невід'ємною складовою побутово-реалістичного і романтичного театрів, доповнювала його психологічну дію, чіткіше окреслювала людські характери. Тут багато важив неповторний чар української народної пісні. Народна пісенна творчість пов'язана і з розвитком професійної української музики ХІХ століття. Українська пісня звучить у багатьох музичних виставах [3, 43].

Народна пісня посідала вагоме місце у творчості провідних оперних співаків, які походять $з$ українського середовища Галичини, О. Мишуги, М. Менцинського, С. Крушельницької, М. Голинського. Саме з народною піснею пов'язані перші кроки їхньої співацької практики, адже вони виховувалися на матеріалі українських пісень, а згодом і популяризували їх.

Зокрема, С. Крушельницька завжди долучала до своїх концертних програм українські народні пісні, які безмежно любила. Непрості суспільнополітичні умови, що не сприяли розвитку тогочасної української культури, не дали змоги зреалізувати С. Крушельницькій свій талант на батьківщині. Та де б не виступала знаменита співачка, вона завжди відчувала себе українкою і прославляла свій народ, його пісні. Вихована на українській народній пісні, вона зробила іiі невіддільною від своєї особистості. Близько сотні

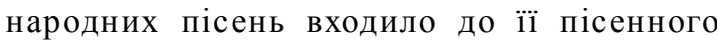


репертуару. Співачка залучала до програм і пісні інших народів світу, проте завжди закінчувала концерт українською. “Вона мені як храм. Я чую в ній органи”, говорила вона про українську пісню [2, 36].

Також С. Крушельницька часто приїжджала до Львова упродовж 1893 - 1914 років і виступала як солістка у Шевченківських концертах хору"Боян" зі співаками О. Мишугою, М. Левицьким, М. Менцинським, Й. Шиманським, Ф. Лопатинською. В їі сольному репертуарі основними були арії з опер, твори М. Лисенка на слова Т. Шевченка і народні пісні. У 1898 році С. Крушельницька провела концертне турне у Львові, Стрию, Станіславі (нині ІваноФранківську), Коломиї, Бережанах, Перемишлі. Про участь співачки у відзначенні 100 -літнього ювілею М. Шашкевича у Львові писав С. Чернецький: “Станула на естраді повитана бурею ентузіастичних оплесків пані С. Крушельницька... За винятком двох італійських пісень, співала самі українські твори з пам'яті, співала так, як лишень Крушельницька вміє співати українську пісню, вкладаючи в ï виконання цілу свою пребагату душу" [2, 97].

Відомо, що 3 піаністом-композитором Б. Дрималиком вона виступала майже у всіх великих містах та селах Галичини, і часто безкоштовно. Як зазначив I. Майчик: "Можна сказати, що Соломії Крушельницькій належить пальма першості щодо популязизації української народної пісні” [2, 25].

Ще один співак світової слави М. Менцинський виконував та популяризував за кордоном українські народні пісні поряд із творами західноєвропейської класики.

У статті “Модест Менцинський і українська пісня” С. Людкевич писав: “Модест Менцинський 3 самого почину своєї кар'єри ставився до української пісні, а головно до Лисенка з великим пієтизмом... I хоч як нині відчужився Менцинський у своїм приватнім житті від нас, то одна хвилина його виступу на естраді перед нами 3 цими кількома піснями була і буде цілком достатньою для того, щоб його відразу з'єднати 3 нами, щоб ми побачили в ньому знов рідного “Модзя”, хоч і співака-артиста європейської міри" [4, $204-205]$.

Програма кожного сольного концерту М. Менцинського вміщувала камерні твори українських композиторів й українські народні пісні. У 1914 році перед поїздкою в Галичину М. Менцинський з Кельна сповістив своєму братові Ф. Колессі таке: “Я вибираюсь на 27 червня до Львова на концерт. Хочу в першій точці співати 3 - 4 народні пісні: а) “Ой, ходив чумак”; б) “Ой, не світи, місяченьку”; в) “Ой, не стелися, хрещатий барвінку”; г) “Ой, я нещасний, що маю діяти?” - або щось у тім напрямі. Може ти зробиш, яку пропозицію? Будь такий добрий” [4, 25].

Отже, відомі співаки, які походили з Галичини, виконували українські народні пісні чи не на кожному своєму концерті, інтерпретуючи ії ніби згусток людського життя, що узагальнює духовнотворчі потенції українства. Високохудожня творчість українських співаків С. Крушельницької, О. Мишуги, М. Менцинського та інших уможливлювалася не лише завдяки впливові італійської вокальної традиції, але й фонетичній довершеності української мови та самобутності багатовікового мелосу нашого народу.

Таким способом, відбувалося піднесення української пісні до професійного рівня. Важливим аспектом функціонування фольклорного матеріалу в співацькому репертуарі $є$ жанр камерно-вокальної обробки, а також наявність рис фольклорного мислення в оригінальній композиторській творчості.

Національно-культурні процеси, що відбувались у Галичині, також великою мірою вплинули на творчість галицьких композиторів XX століття. Їхній доробок характеризує активне засвоєння народнопісенного словника. Особливою рисою творчості видатних галицьких композиторів $\epsilon$ те, що вони втілюють у творах не лише власні творчі задуми, особисте чуття, а й чітке уявлення про образно-емоційну природу національного фольклору.

Звертаючись до фольклорної спадщини, В. Барвінський виявляв дуже обережне ставлення до народної теми. Він уважав, що народна пісня це діамант, шліфований віками. Тому композиторові залишається тільки уважно вдивлятися в бездоганну лінію граней і підібрати відповідну оправу. Особливість обробок В. Барвінського випливає зі специфіки української народної пісенності: це опора на поліфонічність, що випливає 3 традицій українського фольклору, а також завершеність і ясність форми (“Ой ходить сон”, “Ягід-ягілочка”, “Ой ходила дівчина беріжком”, “Чи ти вірно мене любиш”) $[1,3]$.

До національних фольклорних витоків у своїй вокальній творчості також звертався С. Людкевич. Його обробкам народних пісень притаманні такі засади: тонке відчуття народнопісенної системи, яка в будь-якому типі обробки залишається центральним елементом, виразно прослуховується і всіляко акцентується фактурними, гармонічними, регістрово- 


\section{СПАДКОЄМНІСТЬ ПІСЕННО-ФОЛЬКЛОРНОЇ ТРАДИЦІЇ}

\section{В МУЗИЧНОМУ ЖИТТІ ЛЬВОВА КІНЦЯ ХІХ - ХХ СТОЛІТЬ}

тембровими прийомами. Обробки народних пісень композитор писав переважно на підставі особисто записаного і дослідженого фольклорного матеріалу (“Марусенька по саду ходила”, “Дала-с мене мамцю”, “Ой ти дівчино зарученая”, “Ой там із-зі гори”, “Ой, співаночки мої” та ін.).

Народнопісенний фольклор мав величезний вплив на формування композиторського стилю М. Колесси. Він усе життя звертався до фольклору та вважав народну музику основою професійної творчості. Значну частину його вокальних творів становлять обробки лемківського фольклору, для високого голосу в супроводі фортепіано, підготовані у 1933, 1969 та 1973 роках (значна частина 3 них увійшла до збірок "Українські народні пісні Лемківщини” та “Обробки народних пісень”. Циклічні форми обробок представлені композиціями, об’єднаними на підставі регіональної спільності: “Пісні 3 Гуцульщини” (для високого голосу, 1970, для баритона 1978), “Три гуцульські закарпатські пісні” (1978), “Три народні пісні села Ходовичі” (для високого голосу, 1980).

Вокальній музиці належить чільне місце й у творчому доробку А. Кос-Анатольського. Це одна 3 найбагатших і найяскравіших сторінок музичної спадщини мистця, адже пісенність була основною ознакою його творчої ментальності. Обробкам народних пісень А. Кос-Анатольського притаманна більш безпосередня опора на коломийкові ритмоформули, танцювальні жанри (гуцулка, аркан, тропотянку) та певні прийоми народно-інструментального сольного та ансамблевого виконавства, елементи звуконаслідування, гостроінтервальну гуцульську ладовість. Наприклад, обробки народних мелодій “Ой п’ю ж-бо я горілоньку” та “Ой прийшов я до двору”, написані на замовлення С. Крушельницької, стали окрасою їі сольних вечорів. Також композитор створив солоспіви, на кшталт народної пісні та фольклорні обробки (“Одкаль соненько сходило”, “Ти до мене не ходи”, “Чотири воли пасу я").

Також у своїй творчості звертався до буковинського та бойківського регіонального фольклору С. Козак. Успіх і визнання принесли йому пісні “Вівчарик” на слова Г. Коваля, “Верховино, мій ти краю” на народний текст, численні обробки буковинських та галицьких народних пісень.

Яскравим представником індивідуального трактування регіонально-характерного фольклорного матеріалу у поєднанні 3 полістильовими орієнтаціями був професійний фольклорист Д. Задор. Саме це визначило центральне місце у вокальному доробку обробок народних пісень для голосу й фортепіано “Глибока криниця", “Пішов Іван в полонину косити”, “Серед села дичка”, “Легіники”, “Гей, Іване”, “Порізала-м перстик” та інші. У львівський період власної творчої еволюції Д. Задор продуктивно працював над жанром обробки народної пісні, який віддзеркалює його погляди на фольклорний артефакт як узагальнений носій регіонального колориту. В його основі лемківський фольклор, особливо поширений у середовищі львівських митців. Композитор поміркований у новаціях, однак, зберігаючи недоторканність фольклорного зразка у вокальній партії, намагається тонко декорувати текст інструментальними засобами.

Наймасштабнішу частину творчого доробку I. Майчика становлять обробки народних пісень (близько 120 зразків). Вагомим внеском у вітчизняну фольклористику став його збірник “Українські народні пісні Лемківщини в запису та обробці I. Майчика 1980 року”.

Пісенну традицію Галичини підхопили Богдан Янівський, Володимир Івасюк, Ігор Білозір, що у популярній пісенній формі плекали національний дух і спиралися на джерела українського, головно, карпатського фольклору [3, 89].

Варто зазначити й те, що український пісенний фольклор мав великий вплив на становлення музичної освіти Галичини, що починаючи 3 другої половини XIX століття позначена розгортанням музично-освітньої роботи та активізацією багатьох хорів під керуванням відомих диригентів М. Вербицького, I. Лаврівського, А. Вахнянина, О. Нижанківського, Ф. Колесси. “Їхня активна творчо-педагогічна діяльність включала в себе боротьбу за музичну освіту на національно-пісенному грунті 3 урахуванням усього найціннішого з педагогічного досвіду сусідніх народів” $[5,43]$.

Після впровадження реформи шкільництва уперше за всю історію української музичної освіти 3'явилася національна за змістом програма, в основу якої покладено концептуальне положення про українську пісню як могутній чинник національного виховання дитини.

Корифей української музики С. Людкевич, який розпочав свою педагогічну діяльність на початку XX століття, чітко визначав головні напрями розвитку музичного виховання школярів, головним $з$ яких було широке вико-ристання народнопісенної творчості як навчального матеріалу. В підручнику "Матеріали для науки сольфеджіо і хорового співу” С. Людкевич

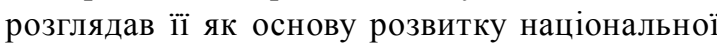
музичної культури й важливий дидактичний засіб музичного виховання дітей. Шлях до пізнання 
підростаючим поколінням історії, традиції рідного народу С. Людкевич вбачав саме через народну пісню. Для співу автор пропонував народні пісні в укладі М. Лисенка, М. Леонтовича, К. Стеценка, В. Матюка.

Західноукраїнські композитори неодноразово зверталися у своїх збірках для дітей до народних пісень (зокрема, В. Матюк - у збірці "Руський співаник для шкіл народних", у підручнику 3 музичної грамоти “Малий катехизм із музики”). Значної уваги народній музиці на Буковині надавав С. Воробкевич у педагогічному посібнику “Співаники” (у 4-х частинах). Його ідеї плідно розвинув та реалізував у власній музичнопедагогічній діяльності Д. Січинський, який створив збірки народних пісень, котрі широко використовували вчителі у шкільній практиці.

Значними явищами галицької музичної педагогіки та видавничої справи стали посібник “Співаймо” (1926), “Збірка народних пісень” (1927) та “Шкільний співаник” Ф. Колесси, виданий 1925 року, відзначався методичною продуманістю, доступністю матеріалу, взятого з народної пісенності; завдяки чому Міністерство освіти у 1927 році затвердило цей співаник як підручник для шкіл 3 українською мовою навчання в Галичині $[5,98]$.

Отже, для народів, які перебували під владою іноземного панування, народна творчість ставала важливим засобом самоусвідомлення, відчуття належності до певної нації. Тому самосвідомість української нації протягом століть бездержавності потужно реалізувалася у музичному мистецтві (найбільше у пісенній творчості) як у формі національно-суспільного самовираження. Тільки завдяки цьому українцям вдалося побутувати як нації і не загубити своєї культури.

Українська пісня стала не лише компонентом духовної надбудови, але й засобом виховання, національної самоідентифікації, виконувала конкретні естетичні, соціально-комунікативні функції.

В українському професійному мистецтві більшою мірою, ніж у багатьох інших національних культурах, зберігся і всебічно розвивається зв'язок з фольклорними витоками. Саме тому серед української інтелігенції письменників, філологів, істориків, музикантів, композиторів зростало зацікавлення фольклором рідного краю. У вокальній та хоровій музиці великого поширення набув жанр фольклорної обробки (опрацювання народнопісенних зразків професійними засобами), народні пісні служать мелодичною основою для вокальних, інструментальних творів, оркестрових композицій, що свідчить про їхній потужний естетично-художній потенціал.
Висновки. Пісенно-фольклорна складова у музичному житті Львова кінця XIX - XX століть була представлена в багатьох напрямах, а саме: в художньо-сценічній діяльності, виконавській інтерпретації, композиторській стилістиці та в музично-освітній сфері.

Отже, питома вага народної пісні в напрочуд інтенсивному музично-культурному житті Львова кінця XIX - XX століть була значною. Більше того: рівень пісенної культури народуГаличини є яскравим показником його загального духовного розвитку.

\section{ЛIТЕРАТУРА}

1. Бабинеиь Н. Д. Обробки народних пісень для голосу з фортепіано Василя Барвінського: метод. Рекомендації / Н. Д. Бабинець. - Львів, 1993. - 21 с.

2. Віночок Соломії Крушельницької: Поезї $i$ музичні твори. Висловлювання визначних діячів культури. Репертуар співачки / упоряд. П. Медведик. - Тернопіль, 1992. - 128 с.

3. Кияновська Л. О. Деякі аспекти стильового аналізу регіональних музичних культур (на прикладі Галичини)/Л. О. Кияновська. // Syntagmation: збірка наукових статей на пошану професора С. Павлишин. - Львів, 2000. - С. 87-99.

4. Модест Менцинський. Спогади / упоряд. М. Головащенко. - К.: Муз. Украӥна, 1978. - 216 с.

5. Черепанин М. В. Музична культура Галичини (друга половина X1X - перша половина XX cm.) М. В. Черепанин. - К.: Вежа, 1997. - 236 c.

\section{REFERENCES}

1. Babinec, N.D. (1993). Obrobki narodnih pisen dlja golosy z fortepiano Vasilja Barvinskogo [Processing of folk songs for voice from Vasyl Barvinsky's piano]. Lviv, 21 p. [in Ukrainian].

2. Medvedik, P. (1992). Vinochok Solomii Kryshelnuckoi: poezii I myzichni tvoru. Vuslovljyvannja vuznachnuh dijachiv kyltyru. Repertyar spivachku [Pottery of Solomia Krushelnytska: Poetry and musical works. Expressions of prominent cultural figures. Repertoire of the singer]. Ternopil, 128 p. [in Ukrainian].

3. Kiyanovskaya, L.O. (2000). Dejaki aspektu stuljovogo analizy regionalnuch myzichnuh kyltyr (na prikladi Galichinu) [Some aspects of stylistic analysis of regional musical cultures (on the example of Halychyna)]. Syntagmation: collection of scientific articles in honor of Professor S. Pavlyshyn. Lviv, pp. 8799. [in Ukrainian].

4. Golovashchenko, M. (1978). Modest Mencinski. Spogadu. [Modest Menzinsky. Memories]. Kyiv: Muzichna Ukraine Publ., 216 p. [in Ukrainian].

5. Cherepanin, M.V. (1997). Myzichna kyltyra Galichina (dryga pollovina XIX-persha pollovina XX st.) [Musical culture of Galicia (second half of XIX - the first half of the XX century) ]. Kyiv: Tower Publ., 236 p. [in Ukrainian].

Стаття надійшла до редакції 02.02.2018 